> Innlegg på inntil $\mathbf{4 0 0}$ ord lastes opp i http://mc.manuscriptcentral.com/tidsskriftet.

Redaksjonen forbeholder seg retten til å foreta redaksjonelle endringer.

Forfattere av vitenskapelige artikler har tilsvarsrett (jf. Vancouver-gruppens regler).

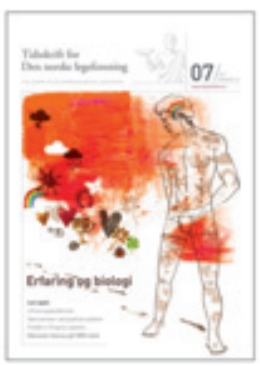

\section{Pandemien i Austevoll}

Det er mykje å lære av rapporten til Sverre Rørtveit og medarbeidarar i Tidsskriftet nr. 7/2011 om influensapandemien i Austevoll (1).

Rørtveit informerte innbyggjarane og førebygde spreiing av influensa. Sjølv om dei fleste e-postane og samtalane hans var med helsepersonell og publikum i kommunen, var det òg mykje kommunikasjon med statlege etatar. Vi i Folkehelseinstituttet vil saman med Fylkesmannen og Helsedirektoratet samordne informasjon og rapporteringsordningar betre neste gong.

I juli 2009 varsla fleire mikrobiologiske laboratorium oss om at analysekapasiteten var sprengd. For å sikre virologisk diagnostikk hos pasientar med auka komplikasjonsrisiko eller alvorlege symptom, måtte prøver frå andre lukast ut. Folkehelseinstituttet sa difor 20.7. 2009 (ikkje 9.9. 2009 som forfattarane skriv) at det ikkje lenger var naudsynt å ta prøve av alle med influensasymptom (2). Vi tok omsyn til overvakinga: «Av overvåkingshensyn ønsker vi inntil videre at det tas prøver av pasienter med typiske symptomer, men ingen kjent eksponering (...).» Som sideverknad vart det vanskelegare for kommuneoverlegane å følgje spreiinga av influensa. Til neste gong må dei mikrobiologiske avdelingane leggje planar for betre analysekapasitet.

Vern av den einskilde mot alvorlege influensakomplikasjonar var det primære omsynet bak Folkehelseinstituttet si tilråding om vaksinasjon $(3,4)$. Difor vart grupper med større risiko for komplikasjonar prioriterte. Vi kunne ikkje la dei vente $\mathrm{i}$ eit forsøk på å stogge epidemien gjennom fyrst å vaksinere skuleborn og andre med stort potensial for vidare spreiing. Dette valet førte til at kanskje dei fleste risikopersonane hadde noko immunitet $\mathrm{i}$ dei vekene eksponeringsfaren var høgst, slik resultata frå Austevoll tyder på (1). Neste gong må vi ha ein kontrakt som sikrar landet vaksine så snøgt som råd er og ha ei von om snøggare produksjon og internasjonal godkjenning av vaksinen.

Vi trur at om lag $20 \%$ av nordmenn vart smitta i $2009(5,6)$, men mange av dei hadde milde eller ingen symptom. Dette passar med at $3 \%$ av austevollingane gjekk til legen med influensa (1). Aldersfordelinga var den same nasjonalt som i Austevoll. Før og etter hovedbølgja dominerte dei vaksne, medan borna dominerte under hovedbølgja. Få eldre vart smitta, og få eldre søkte lege under pandemien. Neste gong vil vi gjere fleire seroepidemiologiske studiar for å følgje pandemien enda betre.

\section{Preben Aavitsland \\ Bjørn G. Iversen}

Hanne Nøkleby

Nasjonalt folkehelseinstitutt

Preben Aavitsland (f. 1963) er assisterende divisjonsdirektør, Divisjon for smittevern, Nasjonalt folkehelseinstitutt.

Bjørn G. Iversen (f. 1962) er avdelingsdirektør ved Avdeling for infeksjonsovervåkning, Nasjonalt folkehelseinstitutt.

Hanne Nøkleby (f. 1948) er divisjonsdirektør ved Divisjon for smittevern, Nasjonalt folkehelseinstitutt.

\section{Litteratur}

1. Rørtveit S, Hunskår S, Wensaas K-A et al. Influensapandemien hausten 2009 i ein vestlandskommune. Tidsskr Nor Legeforen 2011; 131: 675-9.

2. Folkehelseinstituttet. Håndtering av ny influensa A(H1N1) i primærhelsetjenesten. MSIS-rapport 2009; 37: 15. www.fhi.no/dav/3179ec2595.pdf (25.4.2011).

3. Folkehelseinstituttet. Rapport om anbefalt rekkefølge for vaksinering mot ny influensa A(H1N1). Oslo: Folkehelseinstituttet, 2009. www.fhi.no/ dokumenter/ec53d5ef4f.pdf (25.4.2011).

4. Folkehelseinstituttet. Rapport nummer 2 om vaksinasjonsrekkefølge. Oslo: Folkehelseinstituttet 2009. www.fhi.no/dokumenter/f332d0ae39.pdf (25.4.2011).

5. Folkehelseinstituttet. Rapport om scenarier for pandemien og andre influensaepidemier i 2010-2011. Oslo: Folkehelseinstituttet, 2009. www.fhi.no/dokumenter/3c807895b6.pdf (25.4.2011).

6. Waalen K, Kilander A, Dudman SG et al. High prevalence of antibodies to the 2009 pandemic influenza A(H1N1) virus in the Norwegian population following a major epidemic and a large vaccination campaign in autumn 2009. Euro Surveill 2010; 15: pii: 19633. www.eurosurveillance.org/ ViewArticle.aspx?Articleld=19633.(9.5.2011)

\section{RETTELSER}

Influensapandemien hausten 2009 i ein vestlandskommune

Sverre Rørtveit, Steinar Hunskår, Knut-Arne Wensaas, Kristian A. Simonsen, Guro Rørtveit

Tidsskr Nor Legeforen 2011; 131: 675-9

I litteraturlisten er korrekt gjengivelse av referanse 5 og referanse 15 som følger:

5. Folkehelseinstituttet. Statusrapport om ny influensa A (H1N1) versjon 2,23. Oktober 2009. www.fhi.no/dokumenter/0c20db9282.pdf

(12.6.2010).

15. Folkehelseinstituttet. Statusrapport om ny influensa A (H1N1). 8. oktober 2009. www. fhi.no/dokumenter/afee12f0e5.pdf (20.5.2010).

Flere omkostninger ved humanitært arbeid

Tor H. Kristiansen

Tidsskr Nor Legeforen 2011; 131: 801-2

I Tidsskriftet nr. 8/2011 side 802 er det i referanse 1 feil årstall for publisert artikkel. Riktig referanse skulle vært: Flaatten K. Humanitært arbeid må telle. Tidsskr Nor Legeforen 2011; 131: 337.

\section{Tilsvarsrett:}

Tidsskriftet praktiserer tilsvarsrett i henhold til Vancouver-gruppens regler (www.icmje.org/publishing 5 correspond.html).

Dette innebærer at forfattere av vitenskapelige artikler som blir kommentert i spalten Brev til redaktøren, får anledning til å komme med tilsvar i samme nummer av Tidsskriftet. Ytterligere innlegg vil bli henvist til et senere nummer. 